\title{
Evaluation of Serum Testosterone and Prostate Specific Antigen Levels in Sprague-Dawley \\ Female Rats Bearing Mammary Tumours Induced by Dimethylbenz (A) Anthracene
}

\author{
M. R. Abdelgawad and A. F. EL-Kott*
}

Biological Applications Dept, Nuclear Research Centre (NRC), Enshas, Egypt and "Zoology Dept, Faculty of Science, Fayoum University, Egypt.

\begin{abstract}
REAST CANCER is one of the most common malignancies among women in the world and is a leading cause of morbidity and mortality in females of both developed and developing countries. The present work aimed to study the diagnostic value of prostate specific antigen (PSA) for breast cancer and the importance of treatment by blue green algae Spirulina platensis supplementation on PSA and testosterone levels. Two different analytical techniques based on micro particle enzyme immunoassay (MPIA) and enzyme linked fluorescent assay (ILFA) for quantitative determination of total PSA (free PSA and PSA complexed to alpha-1-antichymptrypsin) were studied in the diagnosis of breast cancer before and after Spirulina platensis supplementation.

Female rats secret PSA from female prostate gland, serum testosterone and PSA concentrations were not detected in control and rats supplemented by Spirulina platensis groups.

Serum testosterone and PSA concentration were significantly higher $(P<0.05)$ in rats bearing mammary tumours than rats bearing mammary tumours supplemented with Spirulina platensis. These results suggest that the clinical applicability of total PSA for breast cancer diagnosis and the biological mechanism behind its increase should be further investigated. Finally, the physiological mechanism behind the total PSA increase in breast cancer and its ramifications with respect to tumour progression should be further investigated.

Keywords: Testosterone, prostate specific antigen, breast cancer, female rats.
\end{abstract}

Breast cancer is a leading cause of morbidity and mortality in females of developed countries and is the most common malignancy among North American women (Forbes, 1997). 
It is estimated that by the year 2000, 500,000 women worldwide will die from breast cancer (Forbes, 1997). Currently, the most effective way to minimize morbidity and mortality from breast cancer is by early diagnosis and administration of therapy (Morrison, 1993). It is thus highly desirable to devise new methods of early diagnosis. Mammography is the most sensitive and specific screening modality for breast cancer; however, data presently available do not warrant a universal recommendation for mammography for all women (Ferguson 1997). Breast cancer is one of the most common cancers in the western world. It claimed 40,200 lives in the United States and 13,700 lives in the United Kingdom, respectively in 2003. Considerable variations in incidence and mortality rates exist between different geographic regions. Recent epidemiological studies cited multiple risk factors relating to breast cancer including age, family history, body wt, number of pregnancies, hormone concentration and metabolism, exposure to radiation and breast-feeding. One of the possible explanations for these geographic differences is the variation in environmental exposures including diet (Brekelmans 2003 and Key et al., 2001). In Egypt, breast cancer is the most common cancer among women, representing $18.9 \%$ of total cancer cases (Omar et al., 2003), with an ageadjusted rate of 49.6 per 100,000 population (Ibrahim, 2002).

The human tissue kallikrein family includes 15 genes (KLK1 to KLK15) (Yousef and Diamandis, 2001), clustered in tandem on chromosome 19q13.4. These genes encode for 15 kallikrein proteins (hK1 to hK15), which are all secreted serine proteases. Groups of kallikreins are expressed in many tissues, including the salivary glands, the central nervous system, the skin, endocrine glands such as the testis and ovaries, and hormone-dependent tissues such as the breast, endometrium, and prostate (Yousef and Diamandis, 2001). Among the 15 kallikreins, pancreatic/ renal kallikrein (hK1), glandular kallikrein (hK2) and prostate-specific antigen (hK3; PSA) have been studied the most, and specific biological functions have been assigned to them. The primary function of hK1 is the release of lysyl-bradykinin, a vasoactive peptide (Moreau et al., 2005), hK2 activates the proform of $\mathrm{hK} 3$, and $\mathrm{hK} 3$ is involved in semen liquefaction, increasing the motility of spermatozoa (Rittenhouse et al., 1998). The remaining kallikreins are less well characterized, but they are implicated in a wide range of physiologic functions, from regulation of cell growth to tissue remodelling (Clements et al., 2004). All known kallikreins are under sex-steroid hormone

Egypt. J. Rad. Sci. Applic., Vol. 26, No. 1-2 (2013) 
regulation in cancer cell lines (Yousef et al., 2001). Many kallikreins are known to be up- or down-regulated by steroid hormones in breast and prostate cancer cell lines and may represent important new tumour markers for the diagnosis, monitoring, and treatment of endocrine-dependent malignancies (Yousef and Diamandis, $\left.2002^{\mathrm{a}}\right)$. PSA, a member of the human kallikrein gene family, is a serine protease with chymotrypsin-like activity. The mature form of PSA is a single chain glycoprotein of 237 amino acids containing 7-8\% carbohydrate as a single N-linked oligosaccharide side chain. PSA has a molecular wt of approximately 30,000 daltons (Bélanger et al., 1995 and McCormack et al., 1995). The major site of PSA has also been found in the glandular epithelium of the prostate. PSA has also been found in breast cancers, salivary gland neoplasms, peri-urethral and anal glands, cells of the male urethra, breast milk, blood and urine (Graves, 1995).

PSA produced in the prostate is secreted into the seminal fluid in high concentrations. A major function of PSA is the proteolytic cleavage of gelforming proteins in the seminal fluid, resulting in the liquification of the seminal gel and increased sperm mobility. PSA levels are found in the blood as a result of leakage of PSA from the prostate gland. Increasing levels of serum PSA are associated with prostatic pathology, including prostitutes, benign prostatic hyperplasia and cancer of the prostate (McCormack et al., 1995). PSA occurs in three major forms in blood (i) the major immune detectable form is PSA complexed with the serine protease inhibitor, (ii) alpha-1-antichymotrypsin (PSAACT) and (iii) uncomplexed, or free PSA, is the other immune detectable form of PSA in serum. The majority of free PSA in serum appears to be an inactive form that cannot complex with protease inhibitors and may be either a PSA zymogen or an enzymatically inactive, cleaved form of PSA. A third form of PSA, a complex with alpha-2-macroglobulin, is not detectable with current immunoassays for PSA due to the engulfment and subsequent masking of PSA epitopes by the alpha-2-macroglobulin molecule (Christensson, 1990 and McCormack et al., 1995). PSA is produced by the female breast prior in vitro evidence suggests that, PSA-expression in breast epithelial cells is regulated by androgens and progestins but not estrogens (Sauter et al., 1998). The PSA concentration in female sera is approximately 1000 -fold less than that of males; < $0.004 \mu \mathrm{g} / \mathrm{L}$ (Melegos and Diamandis, 1998). Research in animals suggests the possibility of using PSA as a target for imaging in patients with breast cancer (Black and Diamandis, 2000). 
The present study aimed to through light towards PSA, a possible noninvasive diagnostic marker for breast cancer and the importance of treatment by blue green algae Spirulina platensis administration on PSA and testosterone.

\section{Materials and Methods}

\section{Animals and animal care}

Twenty-eight female Sprague-Dawely rats obtained from Naval American Research Unit (NAMRU) housed and reared in Animal Research Unit, Faculty of Science, Mansoura University, weighing 180-210g were housed in plastic cages. Animals were fed on standard rat chow with tap water ad libitum, randomly divided into 4 groups; each composed of 7 in a cage and mentioned under standard conditions $\left(22 \pm 3^{\circ} \mathrm{C}, 40-70 \%\right.$ relative humidity) as follow; control group, rats supplemented with Spirulina platensis ( $4 \mathrm{~g} / \mathrm{Kg}$ ), rats treated with Dimethylbenz (a) anthracene (DMBA) dissolved in corn oil (30ppm), rats treated with DMBA dissolved in corn oil (30ppm) sc and were supplemented with Spirulina platensis $(4 \mathrm{~g} / \mathrm{Kg})$.

In order to investigate the relation between serum testosterone and PSA levels in late stage mammary gland tumour chemically induced, the present experiment was carried out by treating the rats with DMBA in a single dose of $30 \mathrm{ppm}$ sc and green blue algae Spirulina as food supplementation at a dose of $4 \mathrm{~g} /$ $\mathrm{kg}$ for six months. Spirulina was originated from Wady El-Natroon Lake, provide as axenic culture in laboratory of algal technology, Mansoura University. Spirulina powder was used as $0.4 \%$ food additive. The skin area involved was shaved and sterilized with $70 \%$ alcohol. Animals were killed at the end of experiments and blood was collected for suitable assays.

\section{Histopathological examination}

The rats were palpated regularly for mammary tumours starting from 2 months after treatment. The rats were killed 6 months later, after the initiation of treatment when they became moribund or when a tumour $>2 \mathrm{~cm}$ in diameter was detected in tumour bearing rats using a calibre. The mammary tumours were removed, cut to small pieces and fixed immediately in $10 \%$ phosphatebuffered formalin ( $\mathrm{pH} 7.2)$, embedded in paraffin. Paraffin sections $(4 \mu \mathrm{m}$ in thickness) were prepared and stained with haematoxylin and eosin (H\&E) for histo-pathological examination, using the criteria and classification of mammary tumours as outlined by Young and Hallowes (1973) and Russo et al., (1990).

Egypt. J. Rad. Sci. Applic., Vol. 26, No. 1-2 (2013) 


\section{Measurement of serum testosterone and prostate specific antigen}

To determine the concentrations of serum testosterone and PSA vaginal smears were taken and examined every day during the last month; only rats with regular 4-day oestrous cycles were used. $5 \mathrm{ml}$ of blood were collected in polypropylene plastic tubes without additives at the end of the experiment. After clotting at room temperature, the tubes were centrifuged and the serum was collected. The serum testosterone concentrations were determined by commercial radioimmunoassay (RIA) kit and PSA was determined by two different analytical techniques (1) IM $\mathrm{I}_{\mathrm{X}}$ system total PSA, Abbotte laboratories, USA. Based on MPIA for quantitative determination of total PSA (free PSA and PSA complexed to alpha-1-antichymptrypsin) the analytical sensitivity of the $\mathrm{IM}_{\mathrm{X}}$ system total PSA was better than $0.04 \mathrm{ng} / \mathrm{ml}$. (2) VIDS TPSA is an automated quantitative test for PSA by VIDS analyzer using ILFA, the detection limit is $0.07 \mathrm{ng} / \mathrm{ml}$.

\section{Statistical analysis}

Statistical analyses were carried out using student $t$-test. Data of serum testosterone and prostate specific antigen were given as means \pm S.E. ANOVA was used to compare the means of the groups investigated. Student-NewmanKeuls was used to determine the level of significance between two mean values and Student $t$-test, assuming Gaussian populations with equal SDs. $P$-value $<0.05$ was considered to be statistical significant.

\section{Results}

Serum Testosterone and PSA concentration were not detected in control females' rats and normal rats supplemented with Spirulina platensis in a dose of $4 \mathrm{~g} / \mathrm{kg}$.

TABLE I. Serum concentration of testosterone and prostate specific antigen in different groups.

\begin{tabular}{|c|c|c|c|c|}
\hline \multirow{2}{*}{ Item } & \multicolumn{4}{|c|}{ Experimental groups } \\
\cline { 2 - 5 } & Control & Control+ Spirulina & DMBA & DMBA+ Spirulina \\
\hline Testosterone (ng/ ml) & $<0.1$ & $<0.1$ & $3.77^{\mathrm{a}} \pm 0.15$ & $2.17^{\mathrm{b}} \pm 0.14$ \\
\hline PSA (ng/ ml) by IM & ND & ND & $1.27^{\mathrm{a}} \pm 0.08$ & $0.68^{\mathrm{b}} \pm 0.15$ \\
\hline PSA (ng/ ml) by VIDS & ND & ND & $1.24^{\mathrm{a}} \pm 0.09$ & $0.98^{\mathrm{b}} \pm 0.17$ \\
\hline
\end{tabular}

*Each value was represented as mean \pm S.E of 7 determinations.

*Values with different letters considered significant $(<0.05)$. 
TABLE 2. The difference between IMX system total PSA and VIDS TPSA in control, normal rats supplemented with Spirulina platensis and breast cancer groups.

\begin{tabular}{|c|c|c|c|c|}
\hline \multirow{2}{*}{ Item } & \multicolumn{3}{|c|}{ Experimental groups } \\
\cline { 2 - 5 } & Control & Control+ Spirulina & DMBA by IM $_{\mathbf{X}}$ & DMBA by VIDS \\
\hline PSA (ng/ml) & ND & ND & $1.27^{\mathrm{a}} \pm 0.08$ & $1.24^{\mathrm{a}} \pm 0.09$ \\
\hline \multicolumn{3}{|c|}{ Mean difference } & 0.03 \\
\hline 95\% confidence interval of the difference & \multicolumn{2}{|c|}{-0.2824 to 0.2323} \\
\hline \multicolumn{2}{|c|}{$\boldsymbol{T}$} & 0.2494 \\
\hline \multicolumn{3}{|c|}{ Two tailed P-value } & 0.8075 \\
\hline \multicolumn{2}{|c|}{$\boldsymbol{P}$-value } & $\mathrm{NS}$ \\
\hline
\end{tabular}

Serum Testosterone and PSA concentration were significantly higher $(P<$ 0.05 ) in rats bearing mammary tumours than rats bearing mammary tumours supplemented with Spirulina platensis. The difference between $\mathrm{IM}_{\mathrm{X}}$ system total PSA and VIDS TPSA in control, normal rats supplemented with Spirulina platensis, breast cancer and breast cancer supplemented with Spirulina platensis groups are illustrated in Table $2 \& 3$. The assay of PSA ( $\mathrm{ng} / \mathrm{ml})$ by IMX system minus VIDS in breast cancer induced by DMBA shows: mean difference $=$ $0.03 \mathrm{ng} / \mathrm{ml}, 95 \%$ confidence interval of the difference $=-0.2824$ to $0.2323, \mathrm{t}=$ 0.2494 , two tailed $P$-values 0.8075 and considered not significant (Table 2).

TABLE 3. The difference between IMX system total PSA and VIDS TPSA in breast cancer supplemented with Spirulina platensis groups.

\begin{tabular}{|c|c|c|}
\hline \multirow{2}{*}{ Item } & \multicolumn{2}{|c|}{ Experimental groups } \\
\cline { 2 - 3 } & DMBA+ Spirulina by IM $_{\mathbf{x}}$ & DMBA+ Spirulina by VIDS \\
\hline PSA (ng/ml) & $0.68^{\mathrm{a}} \pm 0.15$ & $0.98^{\mathrm{a}} \pm 0.17$ \\
\hline Mean difference & -0.03 \\
\hline 95\% confidence interval & -0.1940 to 0.794 \\
\hline $\boldsymbol{t}$ & 1.323 \\
\hline Two tailed P-value & 0.2104 \\
\hline $\boldsymbol{P}$-value & $\mathrm{NS}$ \\
\hline
\end{tabular}

The assay of PSA (ng/ ml) by IMX system minus VIDS in breast cancer induced by DMBA supplemented with Spirulina platensis groups shows: mean difference $=-0.03 \mathrm{ng} / \mathrm{ml}, 95 \%$ confidence interval of the difference $=-0.1940$ to $0.794, \mathrm{t}=1.323$, two tailed $P$-values 0.2104 and considered not significant (Table 3). Although no significant correlation in breast cancer group observed between testosterone and PSA antigen concentration $r=-0.37346$, there was a weak correlation in breast cancer group supplemented with Spirulina platensis observed between testosterone and PSA antigen concentration $\mathrm{r}=0.273637$.

Egypt. J. Rad. Sci. Applic., Vol. 26, No. 1-2 (2013) 


\section{Histopathology}

Histo-pathological examination of control and Spirulina platensis treated groups illustrated in Fig. $1^{\text {a\&b }}$ reveal that, mammary glands from age-matched control animals were characterized by a sparse cluster of epithelial tubules, embedded in a small amount of connective tissue, surrounded by a large fat pad. Mammary gland tumour and treated mammary gland tumour with Spirullina platensis are shown in Fig. $1^{\text {c\&d }}$.

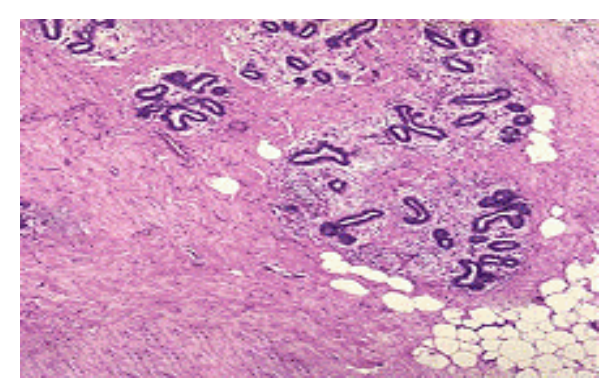

(a) Control

(H\&E 200X).

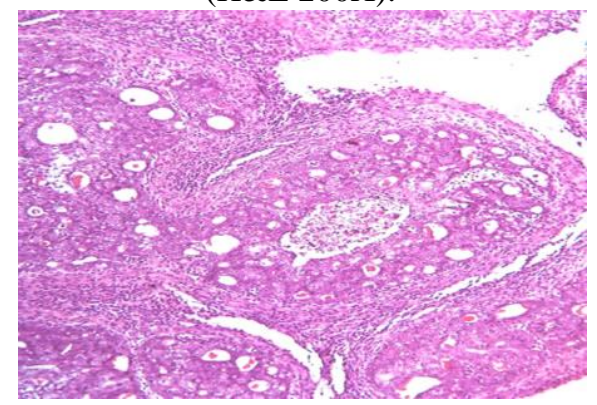

(c) Mammary gland tumour (H\&E 200X).

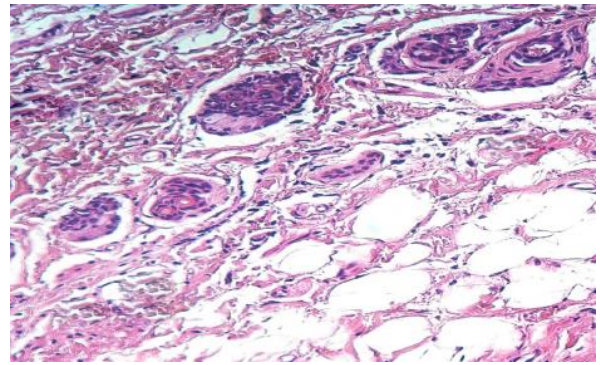

(b) Treated mammary gland with Spirullina platensis (H\&E 400X).



(d) Treated mammary gland tumour with Spirullina platensis (H\&E 400X).

Fig. 1. Control, treated mammary gland with Spirullina platensis, mammary gland tumour and treated mammary gland tumour with Spirullina platensis.

\section{Discussion}

Cancer is a major public health problem in the world. Cancers of the lung and bronchus, prostate and colorectal in men and cancers of the lung and bronchus, breast, and colorectal in women continue to be the most common causes of cancer death. These four cancers account for almost half of the total cancer deaths among men and women. Surprisingly, Breast cancer alone is expected to account for $29 \%(226,870)$ of all new cancer cases among women, 
while, prostate cancer alone will account for 29\% $(241,740)$ of incident cases (Rebecca et al., 2012). In the present study, PSA is secreted in both male and female and may have a value in diagnosis, prognosis and management. Besides, its role in carcinogenesis in both sexes, and that needs further investigations.

Numerous attempts are presently being made to identify serological markers of breast tumours. Prospective markers include carcino-embryonic antigen, carbohydrate antigen 15-3, tissue polypeptide-specific antigen and mammary serum antigen. However, the diagnostic sensitivity of these markers is very limited and does not exceed 32\% (Devine et al., 1995, Eskelinen et al., 1997 and Heinze et al., 1997). Similarly, the results obtained by Sauter et al. (1998) who indicated that the diagnostic sensitivity of free PSA as the predominant molecular form is approximately $20 \%$. However, free PSA as the predominant form is highly specific for breast cancer in comparison with benign breast disease and normal tissue. The high degree of specificity suggests that free PSA may have potential clinical applicability either alone or in combination with other markers.

Clinical trials have shown that spirulina can serve as a supplementary cure for many diseases. Spirulina capsules have proved effective in lowering blood lipid level, and in decreasing white blood corpuscles after radiotherapy and chemotherapy (Ruan et al., 1990). As outlined above, before any speculation can be made regarding the role of mammary PSA, it must first be determined whether the protease has enzymatic activity. No model examining the enzymatic activity of PSA in breast cancer cells has been developed (Killian et al., 1993). Surprisingly, Santos et al. (2006) reported that PSA levels were $0.156 \mathrm{ng} / \mathrm{ml}$ in adult female gerbil rat (desert rat) using subsequent assay. Measurements were done using automated equipment from Vitros-ECi-Johnson and Johnson for ultrasensitive chemiluminescence detection. The sensitivity was $0.1-100 \mathrm{ng} / \mathrm{ml}$ for human PSA. Although the assaying techniques for PSA used in the present study was more sensitive 0.04 and $0.07 \mathrm{ng} / \mathrm{ml}$, respectively, the level of PSA was not detected in both control and normal rats treated with Spirulina platensis, this may be due to different models and assaying techniques used in both studies. It is clear from previous studies that PSA may have a number of potential roles in breast cancer. PSA has been reported to induce uncontrollable proliferation in osteoblast and fibroblast cell lines (Killian et al., 1993). PSA was also shown to stimulate cell detachment, suggesting a role for PSA in Egypt. J. Rad. Sci. Applic., Vol. 26, No. 1-2 (2013) 
tumour progression or metastasis (Webber et al., 1995). It has been demonstrated that PSA degrades the extracellular matrix proteins fibronectin and laminin (Killian et al., 1993). Free PSA as the predominant molecular form is highly specific for breast cancer; its clinical utility is limited at this time due to low sensitivity. Given the heterogeneity of the population of breast cancer patients, additional studies with larger cohorts of patients are required for the examination of molecular forms of PSA with regard to individual parameters such as risk of relapse or metastasis (Black et al., 2000). PSA is a protein produced almost exclusively by the prostate. Although various tissues in females have been found to produce very small amounts of PSA, serum PSA levels in females are quite low and are measurable only with ultrasensitive PSA immunoassays. Research in animals suggests the possibility of using PSA as a target for imaging in patients with breast cancer (Black and Diamandis, 2000). PSA is a normal constituent of female serum (Melegos and Diamandis, 1998) and the possible diagnostic applications of PSA measurements in female serum have been proposed (Zarghami et al., 1997). Numerous studies have shown that PSA is expressed extraprostatically, Diamandis and Yu (1997) suggesting that PSA may be functional outside the prostate gland. The peri-urethral (Skene's) gland was the first female tissue that was suggested to be able to produce PSA (Pollen and Dreilinger, 1984). This tissue has been referred to as the "female prostate" because its developmental origin is homologous to that of the male prostate (Tepper et al., 1984). Therefore, it may not be surprising that this gland produces PSA in both males and females. It is now clear that hormonally regulated tissues in females, such as the breast, can produce PSA. PSA is detectable in normal and hyperplastic breast tissue (Yu et al., 1996) and is present in the majority of breast tumors (Yu et al., 1995 and Yu et al., 1996) and breast cysts (Mannello et al., 1996). PSA gene expression in breast tumours appears to be under hormonal control because the steroid hormone receptorpositive breast cancer cell lines T-47D and BT-474 can be induced by androgens, progestins, mineralocorticoids, and glucocorticoids to produce PSA (Monne et al., 1994) in vitro.

El-kot and Abdelgawad (2009) found that sex hormones have a role in breast carcinogenesis. Furthermore, the results indicated that Spirulina platensis might have therapeutic and protective effects of mammary cancers chemically 
induced in Sprague-Dawely female rats by DMBA and minimize both morbidity and mortality from breast cancer. Sex steroid hormones impact on the initiation and/ or progression of endocrine-dependent malignancies (Lopez-Otin and Diamandis, 1998). As outlined above, most kallikreins appear to be under sex steroid hormonal regulation. Taken together, kallikreins may belong to the targets by which hormones affect the initiation or progression of such tumours (Yousef and Diamandis, 2002-b). Therefore, a better understanding of the hormonal regulation of kallikreins could increase our insights into tumor biology. Mainly cancer cell lines have been studied. The role of sex steroids on the expression of kallikreins has been studied in vivo only for hK2 and hK3 (Obiezu et al., 2000).

Testosterone is converted to a more potent metabolite-dihydrotestosterone. It is degraded in the liver and conjugated for excretion as 17-oxysteroids (Eagon et al., 1994). Testosterone is reduced to $5 \alpha$-dihydrotestosterone by the cytochrome P450 enzyme 5-alpha reductase or converted into estradiol by aromatase enzyme (Meinhardt and Mullis, 2002).

In females, synthesis of estrogens starts in theca interna cells in the ovary by the synthesis of androstenedione from cholesterol. Androstenedione is a substance of moderate androgenic activity. This compound crosses the basal membrane into the surrounding granulosa cells, where it is converted to estrone or estradiol, either immediately or through testosterone. The conversion of testosterone to estradiol, and of androstenedione to estrone, is catalyzed by the enzyme aromatase. Estradiol levels vary through the menstrual cycle, with levels highest just before ovulation (Simpson and Davis, 2001). Santos et al. (2006) indicated that testosterone has a stimulatory effect on the female prostate، inducing epithelial cell proliferation, differentiation, secretory activity, and dysplasia and suggest that prostatic growth and activity, polycystic ovaries, and ovarian stromal cell hyperplasia are related to a hyper androgenic condition in females. Yu et al. (1996) suggest that PSA is expressed frequently by normal breast tissue, by tissue of benign breast diseases, and by breast cancer tissue. Highest expression is seen in benign breast disease and lowest expression in advanced stage cancerous tissue. As PSA production is mediated by steroid hormones and their receptors, we propose that PSA may be a new marker of steroid hormone action in the normal or diseased female breast. The role of this Egypt. J. Rad. Sci. Applic., Vol. 26, No. 1-2 (2013) 
enzyme in the development of breast diseases including breast cancer is currently unknown.

These results suggest that the clinical applicability of total PSA for breast cancer diagnosis and the biological mechanism behind its increase should be further investigated. Finally, the physiological mechanism behind the total PSA increase in breast cancer and its ramifications with respect to tumour progression should be further investigated.

\section{References}

Bélanger, A., Van Halbeek, H., Graves, H. C. B., Grandbois, K., Stamey, T. A., Huang, L., Poppe, I. and Labrie, F. (1995) Molecular mass and carbohydrate structure of prostate specific antigen: Studies for establishment of an international PSA standard. Prostate, 27, 187.

Black, M. H. and Diamandis, E. (2000) The diagnostic and prognostic utility of prostatespecific antigen for diseases of the breast. Breast Cancer Res. Treat., 59, 1.

Black, M. H., Giai, M., Ponzone, R., Sismondi, P., Yu, H. and Diamandis, E. P. (2000) Serum Total and free prostate-specific antigen for breast cancer diagnosis in women. Clin. Cancer Res., 6, 467.

Brekelmans, C. T. (2003) Risk factors and risk reduction of breast and ovarian cancer. Curr. Opin. Obstet. Gynecol., 15, 63.

Christensson, A., Laurell, C. B. and Lilja, H. (1990) Enzymatic activity of prostatespecific antigen and its reactions with extracellular serine proteinase inhibitors. Eur. J. Biochem., 194, 755.

Clements, J. A., Willemsen, N. M., Myers, S. A. and Dong, Y. (2004) The tissue kallikrein family of serine proteases: functional roles in human disease and potential as clinical biomarkers. Crit. Rev. Clin. Lab. Sci., 41, 265.

Devine, P. L., Duroux, M. A., Quin, R. J., McGuckin, M. A., Joy, G. J., Ward, B. G. and Pollard, C. W. (1995) CA 15-3, CASA, MSA, and TPS as diagnostic serum markers in breast cancer. Breast Cancer Res. Treat., 34, 245.

Diamandis, E. P. and Yu, H. (1997) Nonprostatic sources of prostate-specific antigen. Urol. Clin. North Am., 24, 275.

Eagon, P. K., Elm, M. S., Stafford, E. A. and Porter, L. E. (1994) Androgen receptor in human liver: Characterization and quantification in normal and diseased liver. Hepatology, 19, 92.

El-kot, A. and Abdelgawad, M. R. (2009) The protective effect of spirulina platensis against mammary tumors induction by dimethylbenz (a) anthracene in sprague-dawley female rats. Isotop \& Rad. Res., 41, 787.

Eskelinen, M., Kataja, V., Hamalainen, E., Kosma, V. M., Penttila, I. and Alhava, 
E. (1997) Serum tumour markers CEA, AFP, CA 15-3, TPS, and Neu in diagnosis of breast cancer. Anticancer Res., 17, 1231.

Ferguson, J. H. (1997) National Institutes of Health consensus development conference statement: breast cancer screening for women ages 40-49, January 21-23, 1997. J. Natl. Cancer Inst., 89, 1015.

Forbes, J .F. (1997) The incidence of breast cancer: the global burden, public health considerations. Semin. Oncol., 24, S120.

Graves, H. C. (1995) Nonprostatic sources of prostate-specific antigen: a steroid hormone-dependent phenomenon?. Clin. Chem., 41, 7.

Heinze, T., Schurenkamper, P., Minguillon, C. and Lichtenegger, W. (1997) Mammary serum antigen (MSA), Ca 549, CA 15-3 and CEA in breast cancer preoperative sensitivity and correlation to prognostic factors. Anticancer Res., 17, 2953.

Ibrahim, A. S. (2002) Cancer Profile in Gharbiah, Egypt. Methodology and Results. Cairo: Ministry of Health and Population Egypt and Middle East Cancer Consortium.

Key, T. J., Verkasalo, P. K. and Banks, E. (2001) Epidemiology of breast cancer. Lancet Oncol., 2, 133.

Killian, C. S., Corral, D. A., Kawinski, E. and Constantine, R. I. (1993) Mitogenic response of osteoblast cells to prostate-specific antigen suggests an activation of latent TGF- $\beta$ and a proteolytic modulation of cell adhesion receptors. Biochem. Biophys. Res. Commun., 192, 940.

Lopez-Otin, C. and Diamandis, E.P. (1998) Breast and prostate cancer: an analysis of common epidemiological, genetic and biochemical features. Endocr. Rev., 19, 365 .

Mannello, F., Bocchiotti, G., Bianchi, G., Marcheggiani, F. and Gazzanelli, G. (1996) Quantification of prostate-specific antigen immunoreactivity in human breast cyst fluids. Breast Cancer Res. Treat., 38, 247.

McCormack, R. T., Rittenhouse, H. G., Finlay, J. A., Sokoloff, R. L., Wang, T. J., Wolfert, R. L., Lilja, H. and Oesterling, J. E. (1995) Molecular forms of prostate-specific antigen and the human kallikrein gene family: a new era. Urology, 45, 729.

Meinhardt, U., Mullis, P. E. (2002) The essential role of aromatase/p450 arom. Semin. Repod. Med., 20, 277.

Melegos, D. N. and Diamandis, E. P. (1998) Is Prostate-specific antigen present in female serum? Clin. Chem., 44, 691.

Monne, M., Croce, C. M. and Diamandis, E. P. (1994) Molecular characterization of prostate-specific antigen messenger RNA expressed in breast tumors. Cancer Res., 54, 6344.

Moreau, M. E., Garbacki, N., Molinaro, G., Brown, N. J., Marceau, F. and Adam,

Egypt. J. Rad. Sci. Applic., Vol. 26, No. 1-2 (2013) 
A. (2005) The kallikrein-kinin system: current and future pharmacological targets. J. Pharmacol. Sci., 99, 6.

Morrison, A. S. (1993) Screening for cancer of the breast. Epidemiol. Rev., 15, 244.

Obiezu, C. V., Giltay, E. J., Magklara, A., Scorilas, A., Gooren, .L. J., Yu, H., Howarth, D. J. and Diamandis, E. P. (2000) Serum and urinary prostatespecific antigen and urinary human glandular kallikrein concentrations are significantly increased after testosterone administration in female-to-male transsexuals. Clin. Chem., 46, 859.

Omar, S., Khaled, H., Gaafar, R., Zekry, A.R., Eissa, S. and El-Khatib, O. (2003) Breast cancer in Egypt: a review of disease presentation and detection strategies. East Mediterr. Health J., 9, 448.

Pollen, J. J. and Dreilinger, A. (1984) Immunohistochemical identification of prostatic acid phosphatase and prostate specific antigen in female periurethral glands. Urology, 23, 303.

Rebecca, S., Naishadham, D. and Jemal, A. (2012) Cancer Statistics, 2012. CA Cancer J. Clin., 62, 10.

Rittenhouse, H. G., Finlay, J. A., Mikolajczyk, S. D. and Partin, A. W. (1998) Human kallikrein 2 (hK2) and prostate-specific antigen (PSA): two closely related, but distinct, kallikreins in the prostate. Crit. Rev. Clin. Lab. Sci., 35, 275.

Ruan, J. S., Guo, B. J. and Shu, L. H. (1990) Effect of Spirulina polysaccharides on changes in white blood corpuscles induced by radiation in mice. J. Radiat. Res. Technol., 8, 210.

Russo, J., Russo, I. H., Rogers, A. E., VAN Zwieten, M. J., Gusterson, B. (1990) Tumors of mammary gland. In: Turusov V, Mohr U (eds) Pathology of tumours in laboratory animals. Vol. 1, pp. 47-78. IARC Scientific Publications, Lyon.

Santos, F. C. A., Leite, R. P., Custodio, A. M. G., Carvalho, K. P., Monteiro-Leal, L. H. Santos, A. B., Go'es, R. M., Carvalho, H. F. and Taboga, S. R. (2006) Testosterone stimulates growth and secretory activity of the female prostate in the adult Gerbil (Meriones unguiculatus). Biol. Reprod., 75, 370.

Sauter, E. R., Babb, J., Daly, M., Engstrom, P. F., Ehya, H., Malick, J. and Diamandis, E. (1998) Prostate-specific antigen production in the female breast: association with progesterone. Cancer Epidemiol. Biomark. Preven., 7, 315 .

Simpson, E. R. and Davis, R. (2001) Minireview: aromatase and the regulation of estrogen biosynthesis-some new perspectives. Endocrinology, 142, 4589.

Tepper, S. L., Jagirdar, J., Heath, D. and Geller, S. A. (1984) Homology between the female paraurethral (Skene's) glands and the prostate. Immunohistochemical demonstration. Arch. Pathol. Lab. Med., 108, 423. 
Webber, M. M., Waghray, A. and Bello, D. (1995) Prostate-specific antigen, a serine protease, facilitates human prostate cancer cell invasion. Clin. Cancer Res., 1, 1089.

Young, S. and Hallowes, R. C. (1973) In International Agency for Research on Cancer, Volume 1, $1^{\text {st }}$ edition. Edited by Turusov VS. Lyon; P.P. 31-74.

Yousef, G. M. and Diamandis, E. P. (2001) The new human tissue kallikrein gene family: structure, function, and association to disease. Endocr. Rev., 22, 184.

Yousef, G. M. and Diamandis, E. P. $\left(\mathbf{2 0 0 2}^{\mathbf{a}}\right)$ Human tissue kallikreins: a family of new cancer biomarkers. Clin. Chem., 48, 1198.

Yousef, G. M. and Diamandis, E. P. $\left(\mathbf{2 0 0 2}^{\mathbf{b}}\right)$ Human tissue kallikreins: a new enzymatic cascade pathway?. Biol. Chem., 383, 1045.

Yousef, G. M., Scorilas, A., Jung, K., Ashworth, L. K. and Diamandis, E. P. (2001) Molecular cloning of the human kallikrein 15 gene (KLK15). Up-regulation in prostate cancer. J. Biol. Chem., 276, 53.

Yu, H., Giai, M., Diamandis, E. P., Katsaros, D., Sutherland, D. J. A., Levesque, M. A., Roagna, R., Ponzone, R. and Sismondi, P. (1995) Prostate-specific antigen is a new favorable prognostic indicator for women with breast cancer. Cancer Res., 55, 2104.

Yu, H., Diamandis, E. P., Levesque, M., Giai, M., Roagna, R., Ponzone, R., Sismondi, P., Monne, M. and Croce, C. M. (1996) Prostate specific antigen in breast cancer, benign breast disease and normal breast tissue. Breast Cancer Res. Treat., 40, 171.

Zarghami, N., Grass, L., Sauter, E. R. and Diamandis, E. P. (1997) Prostate-specific antigen levels in serum during the menstrual cycle. Clin. Chem., 43, 1862.

(Received: 30/09/2013;

accepted: 08/12/2013)

Egypt. J. Rad. Sci. Applic., Vol. 26, No. 1-2 (2013) 


$$
\begin{aligned}
& \text { تقييم مستوى التستوستيرون والمستضد الخـاص بالبروستاتا }
\end{aligned}
$$

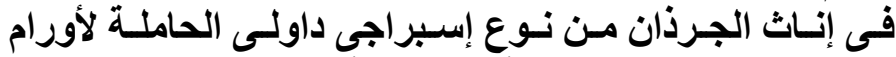

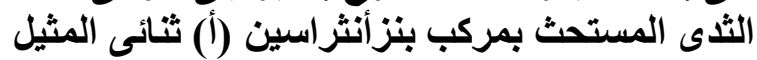

$$
\begin{aligned}
& \text { محمد رمضان عبد الجواد ، و *عطا الله فرج القط }
\end{aligned}
$$

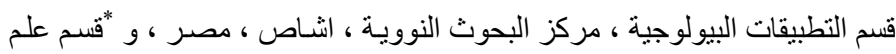

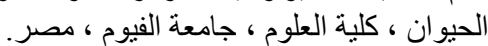

\footnotetext{
يعد سرطان الثذي من أكثر الأور ام شيو عا بين نساء العالم و الذي يهدد

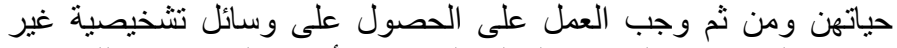

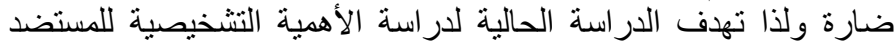

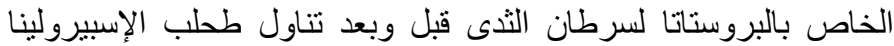

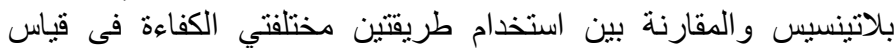

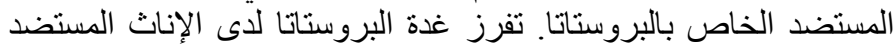

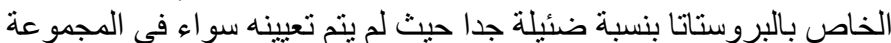

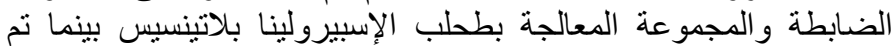

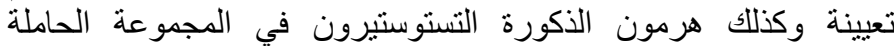

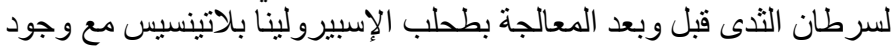
فروق معنوية فى التمييز بينهما. تخلص هذه التها الدار اسة إلى إمكانية استخدام

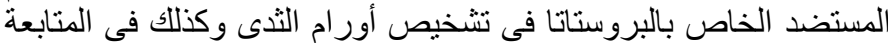

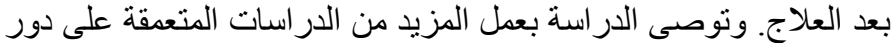
المستضد الخاص بالبروستاتا وهرمون الذكورة التستوستيرون في عملية السرطنة بمختلف مر احلها.
} 